\title{
Understanding and Protecting Vulnerable Financial
}

\section{Consumers}

\author{
PETER CARTWRIGHT*
}

*Professor of Consumer Protection Law, School of Law, University of Nottingham Email

Peter.Cartwright@ nottingham.ac.uk. Some of the research for this article was funded by the Financial Services

Research Forum and I am grateful to the Forum for its support. Thanks too to Geraint Howells and Colin Scott for comments on an earlier draft. The usual disclaimers apply. 


\title{
Understanding and Protecting Vulnerable Financial
}

\section{Consumers}

\begin{abstract}
This article considers how consumer protection law and policy should address the interests of particularly vulnerable financial consumers. Specifically, the article proposes a taxonomy of vulnerability which helps to identify (a) what makes consumers particularly vulnerable, and (b) how consumer protection law and policy can respond to these causes in a way that provides such consumers with appropriate protection. Changes to economic conditions, legal requirements on traders and our understanding of consumer behaviour make discussion of these issues particularly topical. There is little doubt that finding solutions is extremely difficult. Trade offs are necessary and some enduring factors that contribute to vulnerability, in particular poverty, sometimes appear intractable. Nevertheless, it is submitted that by identifying clearly both why consumers are vulnerable and how the factors that lead to such vulnerability can be addressed, it is possible to construct an environment which respects consumer choice while ensuring that the most vulnerable are protected appropriately.
\end{abstract}

Keywords: consumer protection, vulnerability, regulation, consumer policy.

Note: Consumer Focus defined consumers in vulnerable positions as: 'People who cannot choose or access essential products and services which are suitable for their needs or cannot do so without disproportionate effort/cost/time', http://www.consumerfocus.org.uk/topic/vulnerable-consumers 


\section{Introduction}

Protecting consumers is an obvious objective of regulating markets, but are a heterogeneous group. Ensuring appropriate protection is therefore, extremely difficult. Of particular concern is how the interests of particularly disadvantaged (or in the language of this article, vulnerable) consumers are addressed. The purpose of this article is to consider how consumer protection law and policy should address the interests of (particularly) vulnerable financial consumers. Specifically, the article proposes a taxonomy of vulnerability which helps to identify (a) what makes consumers particularly vulnerable, and (b) how consumer protection law and policy can respond to these causes in a way that provides such consumers with appropriate protection.

The article begins by examining the meaning(s) of vulnerable and disadvantaged consumers. It then proposes the taxonomy of vulnerability and identifies how each element of vulnerability might be tackled. Finally, conclusions are drawn.

\section{Defining Vulnerable and Disadvantaged Consumers}

Consumers will sometimes be so vulnerable that they lack capacity and it is important that the law makes provision for such circumstances. ${ }^{1}$ This article, however, is concerned with

\footnotetext{
${ }^{1}$ See the Mental Capacity Act 2005.
} 
individuals who have capacity, but who are particularly vulnerable when acting or seeking to act as consumers.

There is debate about whether such consumers are better described as vulnerable or disadvantaged (Consumer Affairs Victoria (2004); Menzel Baker et al (2005); Morgan et al (1995)). A vulnerable consumer might be viewed as one who "is capable of readily or quickly suffering detriment in the process of consumption" while a disadvantaged consumer is 'a person in persistent circumstances and/or with ongoing attributes which adversely affect consumption thereby causing a continuing susceptibility to detriment in consumption (Consumer Affairs Victoria (2004) p 3).' This definition of vulnerability is extremely broad; many consumers are capable of suffering detriment readily or quickly, even if they are generally well-placed to make informed decisions. The definition reflects the authors' view that consumer vulnerability involves exposure to the risk of detriment whether it results from personal or market dimensions. The personal dimension includes the attributes and circumstances of individuals which affect consumption decisions such as personal capacities, preferences, income and the context in which individuals consume. The market dimension relates both to the nature of markets generally, and the characteristics of the specific market in issue (Consumer Affairs Victoria (2004)). This definition of disadvantage emphasises persistent circumstances and ongoing attributes; indeed, the distinction between vulnerability and disadvantage 'rests on the persistence of a specific adverse circumstance or condition causing vulnerability (Consumer Affairs Victoria (2004) para 6.4) Thus, temporary circumstances, such as illness, may make a consumer vulnerable, but not necessarily disadvantaged, while disadvantaged consumers will, almost inevitably, be vulnerable consumers. Examples of relevant circumstances and attributes might be disability; illiteracy; gullibility; low income, low confidence and geographical location. 
The vulnerable alternatively might be described as those that are 'at a disadvantage in exchange relationships where that disadvantage is attributable to characteristics that are largely not controllable by them at the time of the transaction.' (Andreasen and Manning (1990) p 13). While this definition appears wide enough to cover temporary vulnerability, the authors' examples of vulnerable groups (children, the elderly, the uneducated, the structurally poor, the physically handicapped, minorities and those with language problems) imply that temporary vulnerability (such as that resulting from bereavement) may not involve a 'characteristic'. The authors, therefore, see vulnerability as something that persists.

Wilhelmsson distinguishes vulnerable consumers from 'less privileged' consumers, and uses the latter term to refer primarily to wealth and social status. (Wilhelmsson (2007) p 213) He avoids labelling consumers as vulnerable, viewing the term as stigmatic. Indeed, some regard the very concept of consumer vulnerability as 'crude and unhelpful', preferring to describe certain consumers as 'at a disadvantage' (George and Leonard (2007) p 56). Nevertheless, they recognise that some people will be vulnerable in some way.

This article agrees that 'vulnerable consumers' do not constitute a discrete homogeneous group and that different consumers will be particularly susceptible to detriment in different circumstances. It uses the concept of consumer vulnerability as shorthand to reflect the elements that are liable to create a particular susceptibility to detriment beyond the norm, and sees vulnerable consumers as those that display those elements. This is explained below in the context of the taxonomy of vulnerability.

\section{Conceiving and Addressing Consumer Vulnerability: the Taxonomy of Vulnerability}


The Rationales for Regulation and the Taxonomy of Vulnerability

To understand how the suggested taxonomy of vulnerability reflects why consumers are liable to be vulnerable it is important to consider how it relates to the way markets are deemed to operate in classical economic theory (while recognising the limitations of such an approach).

First, in the perfect market of classical economic theory, rational and well-informed consumers make consistent decisions in accordance with their preferences and so exert market discipline. Where information asymmetry exists between supplier and consumer, intervention (such as though mandatory disclosure) may play a role in helping to correct this. While many consumers suffer from information asymmetry, those for whom that asymmetry is greatest are especially vulnerable, and therefore deserve particular attention. This is referred to here as informational vulnerability. Second, in the perfect market transactions are fully voluntary. In practice, by contrast, consumers may be particularly vulnerable as a result of their greater susceptibility to pressure. This is described as pressure vulnerability. Third, the perfect market contains numerous buyers and sellers, while in practice a small number of firms may be dominant or consumers may otherwise lack choice. This is described here as supply vulnerability. Next, perfect markets are underpinned by private law, which allows consumers to hold traders to account for breaches. However, the availability of such remedies may be more apparent than real, with some consumers finding it particularly difficult to obtain redress. This is referred to here as redress vulnerability.

These elements of vulnerability might be tackled in a variety of ways. Some solutions, such as improving information, increasing supply, and facilitating redress, are generally 'market friendly' in the sense that they focus on improving the ability of the consumer to operate 
within the market. However, there is a danger that by focusing simply on improving the market, some consumers will be left even more vulnerable than they were before. It has been pointed out that where consumer law concentrates on tackling market failure, for example by improving the supply of information or the ability to seek redress, the results may be regressive (Wilhelmsson (1997)). That does not mean that we should abandon such initiatives, but serves as a reminder that addressing the interests of vulnerable consumers demands a multi-faceted response. This article consequently suggests that there is a final element of vulnerability, which reflects the greater harm, or loss suffered by particular consumers from sub-optimal decisions. This is described here as impact vulnerability.

\section{Identifying Informational Vulnerability}

An enormous amount has been written on the role of information in consumer protection and it has been argued that rectifying information asymmetry was the 'key analytical basis for early consumer protection law' (Hadfield Howse and Trebilcock (1998) p 134). Burden argues that consumers may be vulnerable for two main reasons: first, because they may find it more difficult to obtain or to deal with information needed to make appropriate purchasing decisions, and second, because they may suffer greater loss than other consumers by making inappropriate purchasing decisions (Burden (1998). The first point is central to this part of the discussion.

In relation to obtaining information, difficulties may result from a variety of factors. For example, some consumers will not be able to access sources of information, perhaps because of physical disability or unfamiliarity with information technology. Others may miss useful information through being excluded from marketing (Kempson and Whyley (1999)). It is well-established that rational traders may be reluctant to give consumers information from 
which such consumers would benefit. Reasons for this reluctance include because it places their products in an unfavourable light, is difficult or uneconomic to communicate effectively, or is liable to reduce overall demand for the class of products (London Economics (1998)). The reluctance of traders voluntarily to disclose affects all consumers, but may particularly exacerbate the situation of some. Furthermore, it has been argued that some consumers may be less inclined to seek out information, perhaps through lack of confidence or because of negative previous experiences (Consumer Affairs Victoria (2004). In terms of processing information, Ringold describes vulnerable consumers as those who have 'diminished capacity to understand the role of advertising, product effects or both' (Ringold (1995) p 584). This illustrates the importance of individual characteristics in understanding informational vulnerability. Some consumers will be unable to play the role traditionally expected of consumers by classical economics - that of rational maximisers of their own utility - because of individual characteristics that inhibit their ability to deal with information. These characteristics may have organic or experiential bases. Traders who are aware of such characteristics may, of course, take advantage of them.

\section{Addressing Informational Vulnerability}

\section{Mandatory Disclosure}

If many consumers are not receiving the information they need to make informed choices then mandatory disclosure is an obvious response. Disclosure has several attractions as an instrument of consumer policy. It is (relatively) inexpensive and market friendly. It also respects consumer choice, thus preserving autonomy (Beyer (1992)). By encouraging consumers to take responsibility for their decisions it also minimises moral hazard, the tendency to take risks for which they do not bear the consequences. Despite these strengths, it has limitations, and these may be particularly great for vulnerable consumers. 
First, to make fully informed choices consumers particularly need information on price, quality and terms of trade (London Economics (1997)). Price is typically easier to communicate than quality and this leads to problems, both in regulatory design and in the response of firms to it. For example, difficulties in conveying quality may produce focal point competition, with firms focusing on one aspect of a product at the expense of others (London Economics (1997)). Furthermore, bad products may drive good products out of the market, with suppliers under little incentive to provide high quality high price goods that they have difficulty distinguishing (Akerlof (1970)). In addition, some aspects of quality, such as reliability and durability, may be particularly difficult to identify or communicate, only becoming apparent in the future.

Second, because consumers differ in the information they would find useful, there is a danger of information overload, with regulators insisting that a wide range of information be disclosed. This may be counter-productive, either confusing many consumers, or leading to their ignoring the information (Simon (1982)). It is reasonable to assume that some consumers will find an excess of information particularly troubling.

Third, disclosure requires a response from consumers. It has been suggested that frequently 'consumers are unaware of the information disclosed, do not appreciate its significance, or simply do not employ the information provided in the marketplace' (Scott and Black (2000) p 372). Indeed, it has been argued that disclosure reproduces or amplifies injustice, because the consumers most in need of protection do not use it (Wilhelmsson (1997)). 
A final point is that disclosure is to a large extent based on the assumption that consumers act rationally, in the sense of acting consistently in accordance with their preferences. However, recent studies in behavioural economics have challenged these assumptions (Hansen and Kysar (1999); Jolls, Sunstein and Thaler (1988)). For example: consumer preferences typically vary over time (usually with a preference for the short term); they tend to be overoptimistic; they respond very differently depending upon how questions are presented, and they tend to use heuristics (rules of thumb) to assess factors such as risk (Ramsay (2007). While these biases may affect a large proportion of consumers, they are particularly problematic for those with less experience, or with poor literacy or numeracy skills. Cayne and Trebilcock, while sympathetic to disclosure, argue that it only succeeds if the consumer 'is intellectually and psychologically equipped to apply the information which disclosure regulation entitles him to have' (Cayne and Trebilcock (1973) p 406). It is unclear how many consumers are intellectually and psychologically equipped to make well-informed choices.

If informational vulnerability is to be tackled through disclosure, certain steps are essential. First, there should be a sharp focus on providing the information that is of particular importance to vulnerable consumers. This might, in appropriate cases, include warnings about matters that would be obvious to many consumers, but not all. Where products are particularly likely to be used by vulnerable consumers, key warnings should be (a) phrased very simply and directly; and (b) especially prominent. In appropriate cases, messages might be effectively conveyed by images rather than text. It has recently been suggested that information is most likely to achieve its goals in changing behaviour where: it is clear who the information is aimed at; language is accessible to the lowest ability group likely to access it; volume is minimised to maximise impact; the sources of competition for attention are 
identified and overcome; and visual tools are used to guide choices (BRE 2 (undated)) p 14). ${ }^{2}$ The second point suggests that regulated information be driven by the lowest common denominator in terms of reading age but that in designing information for the most vulnerable consumers all society will benefit from simple, concise messages.' (BRE 1 (undated) $\mathrm{p} 13)^{3}$ It should also be noted that simple disclosures, such as telling consumers where to go for advice can make a significant difference in encouraging them to act (Andreasen and Manning).

Second, there should be greater emphasis on improving the ability of consumers to recognise and act upon information, for example through advertising campaigns and consumer education. Indeed, improving consumer education should help to tackle different aspects of vulnerability. For example, making poor decisions less likely minimises impact vulnerability, while improving assertiveness should both minimise the effect of pressure vulnerability and, by making consumers more willing to pursue their rights, reduce redress vulnerability. Using education to improve consumer awareness and competence is a long-term strategy but a valuable one.

A third point is that it is necessary to look beyond disclosure and education if consumers are to be persuaded towards socially more desirable outcomes. Indeed, it has been argued that education is really a misnomer in the area of consumer policy: 'our aim is not to get people to know more things. We are trying to get people to change what they do (Robinson (2006))., ${ }^{4}$ While education can play a role in this, other tools may be more effective including prompts, nudges, default options and incentives. It is not possible to examine all these in the paper

\footnotetext{
${ }^{2}$ BRE/BERR/NCC Warning! Regulated Information: a Guide for Policy Makers (undated ) 14.

${ }^{3}$ BRE/BERR/NCC Warning: Too Much information can harm (Final Report, undated) 13.

${ }^{4}$ L Robinson "A 7 step social marketing approach" paper at the Waster Educate 98 Conference cited in Consumer Affairs Victoria Social Marketing and Consumer Policy (Research paper no.4 March 2006).
} 
although some are considered later. Suffice it to say that it is hard to disagree with the conclusion of Howells that 'a more sophisticated and nuanced approach to information rules should be developed which enhances the effectiveness of the rules, whilst recognising their limitations.' (Howells (2005)) $)^{5}$

\section{Controlling False and Misleading Information}

Consumers may also be vulnerable through a particular susceptibility to being misled. A vital question concerns how information should be judged. While applying an objective standard of the reasonable, or average consumer may be attractive from the perspective of being (relatively) easy to apply, such a standard could incentivise less reputable firms to take advantage of the "ignorant, the unthinking and the credulous". 6 The Unfair Commercial Practices Directive illustrates the dilemma. While taking as a benchmark the average consumer who is "reasonably well informed and reasonably observant and circumspect" the Directive allows practices to be judged from the perspective of the average member of a group where the practice is targeted at that group. Furthermore, recital 10 of the Directive states:

"where certain characteristics such as age, physical or mental infirmity or credulity make consumers particularly susceptible to the underlying product and the economic behaviour of only of such consumers is likely to be distorted by the practice in a way that the trader can reasonably foresee, it is appropriate to ensure that they are adequately protected by assessing the practice from the perspective of the average member of that group."

It is through this provision that account can be taken of vulnerable consumers for whom certain practices may be misleading (or, as will be seen later, aggressive). Allowing the

\footnotetext{
${ }^{5}$ Howells (n 13) 362.
} 
standard to be varied might be justified on different grounds. First, by encouraging traders to consider how potentially ambiguous statements might be understood, the clarity and quality, of information are improved. Second, not all consumers can meet the standards a purely objective test would require of them. Any costs of greater scrutiny benefit the vulnerable, but are borne by all. This might be supported on the basis of distributive justice. Third, the test may assist in reinforcing trust. ${ }^{7}$. But concerns remain. It has been suggested that 'almost all substantive advertisements will deceive at least some people in the light of the exceptional heterogeneity of listeners and viewers' (Sunstein (1997)). ${ }^{8}$ Traders are likely to baulk at a test which requires them to consider how the average consumer with a mental infirmity might have understood a marketing campaign. It is submitted that the test is flexible enough to allow the courts to come to sensible conclusions, particularly because of the steer they are given by the legislation.

\section{The Relationship between Information Tools}

As well as tackling misleading actions, the Directive also prohibits misleading omissions. Article 7(1) states that a commercial practice is a misleading omission if, in its factual context, taking account of a series of matters, it inter alia "omits material that the average consumer needs, according to the context, to take an informed transactional decision." Article $7(2)$ suggests further than providing material information in "an unclear, unintelligible, ambiguous or untimely manner" will also amount to a misleading omission. This blurs the distinction between actions and omissions and the provisions raise a number of practical difficulties. The courts will have to consider the factual context of the transaction and the limitations of the medium used to communicate the practice, and there is the question of

\footnotetext{
${ }^{7}$ I Ramsay Advertising Culture and the Law (Sweet and Maxwell London 1996) 85.

${ }^{8}$ Sunstein (n 30) 284.
} 
when the consumer 'needs' rather than simply would benefit from particular information. ${ }^{9}$ Nevertheless, the provision is a significant innovation and reveals an increasing willingness to require traders to inform consumers about matters that are likely to be of significant interest to them. ${ }^{10}$ The test of the vulnerable consumer again becomes relevant here. Information may be material to some consumers that would not be to others and there is an obligation on traders to ensure that vulnerable consumers are given the information that they need to make an informed choice in the circumstances identified.

\section{Identifying Pressure Vulnerability}

In the perfect market the consumer's actions are fully voluntary, but in practice consumers sometimes make decisions under pressure. A study by the UK's Department of Trade and Industry in 2003 identified being subjected to high pressure sales techniques as one of the principal problems faced by vulnerable consumers across the various countries studied (DTI, 2003)). ${ }^{11}$ There may be overlap with other aspects of vulnerability; for example, consumers may be more easily pressurised into making a decision if they lack relevant information, such as about their options. However, there will be cases where information asymmetry is not the essence of the vulnerability, but power asymmetry is. Indeed, it has been suggested that all consumer problems result from one or more of a disparity of bargaining power, knowledge and resources (Ziegel (1973)). ${ }^{12}$ The three clearly are connected. For example, the inability to bargain effectively may arise from factors such as lack of knowledge and lack of choice. However, it may also result from a feeling of inferiority or susceptibility. The pressure felt by consumers may arise from individual characteristics (such as age, lack of confidence or

\footnotetext{
9 The High Court interpreted "needs" narrowly in OFT v Purely Creative (n 46) para 74.

${ }^{10}$ H Collins 'Harmonisation by Example: European Laws against Unfair Commercial Practices' (2010) 73(1) MLR 89-118, 104-105.

${ }^{11}$ DTI Comparative Report on Consumer Policy Regimes (DTI, London Oct 2003) 9.

12 J Ziegel 'The Future of Canadian Consumerism' (1973) Canadian Bar Review 190. Cited in I Ramsay (n 33) 53.
} 
knowledge) temporary individual circumstances (such as the loss of a loved one or similar life event) or physical situation (such as the presence of the seller in the buyer's home). It may also stem from the behaviour of the seller (for example acting in an intimidating manner). Furthermore, pressure is likely to be greatest when the consumer is in financial difficulty. As Best observes 'being poor and subject to stressful financial circumstances can cloud one's judgment, making one far more receptive to disadvantageous business dealings'. (Best $(1981))^{13}$ Consumer protection law requires mechanisms which allow these to be addressed, but difficult policy issues arise. One problem is that some power asymmetry is inevitable, the fundamental question often being 'whether the promisee should be permitted to exploit his advantage to the detriment of the other party' (Kronman (1980)) ${ }^{14}$ While physical intimidation would doubtless justify a remedy, psychological pressure is more problematic. We might, for example, identify certain consumers as vulnerable because of their susceptibility to having their emotional weaknesses exploited (Ramsay (date)) ${ }^{15}$ The distinction between exploitative and persuasive trade practices is often contestable.

\section{Addressing Pressure Vulnerability}

\section{Banning High-Pressure Practices}

One response to pressure vulnerability is to ban practices where such vulnerability is particularly likely to be found, such as doorstep selling. In the 1960s the Molony Committee saw doorstep selling as 'a serious social evil.' (Molony (date)) and in 2002 Citizen's Advice made a super-complaint to the Office of Fair Trading about the practice. The Directive lists 31 commercial practices which are considered unfair in all circumstances (and so essentially prohibited). Several are unfair because of the pressure they involve, including creating the impression that the consumer cannot leave the premises until a contract is formed, and

\footnotetext{
${ }^{13}$ A Best When Consumers Complain (Columbia University Press, New York 1981) 28.

${ }^{14}$ A Kronman 'Contract Law and Distributive Justice' (1980) Yale LJ 472-511, 480.

${ }^{15}$ Ramsay (n 33) 423-424.
} 
conducting personal visits to the consumer's home ignoring the consumer's request to leave or not to return (except in limited circumstances). Where conduct falls clearly within one of the practices it can be dealt with relatively simply. Provided there is adequate enforcement, the banning of particularly egregious practices is a simple and direct way of tackling pressure vulnerability.

\section{Prohibiting Aggressive Commercial Practices Through Broad Standards}

Perhaps the main way that consumer protection law addresses pressure vulnerability is by prohibiting aggressive practices through broad open texture standards (Cartwright (2011)). ${ }^{16}$ Article 8 of the Directive states that a commercial practice is aggressive if :

"in its factual context, taking account of all its features and circumstances, by harassment, coercion, including the use of physical force, or undue influence it 'significantly impairs or is likely to significantly impair the average consumer's freedom of choice or conduct with regard to the product and thereby causes him or is likely to cause him to take a transactional decision that he would not have taken otherwise'.

Article 9 then explains that in determining whether a commercial practice uses harassment, coercion or undue influence account shall be taken of a variety of factors, including timing, persistence, and exploitation of misfortune.

These novel provisions only apply where the practice impairs, or be likely significantly to impair, the average consumer's freedom of choice or conduct, and where it causes or is likely to cause him to take a transactional decision he would not have taken otherwise. Merely

\footnotetext{
${ }^{16}$ See P Cartwright ‘Under Pressure: Regulating Aggressive Commercial Practices in the UK' [2011] Feb LMCLQ 123-141.
} 
irritating or upsetting practices are not covered (Howells et al (2006)) ${ }^{17}$ The ability to vary the average consumer standard, discussed above in the context of misleading practices, will be important in some cases. Account may be taken, for example, of consumers who might not be expected to withstand the same pressure as the typical consumer. For example, a consumer's desperate financial position might be relevant in some cases of undue influence. While harassment and coercion are not defined, they include both physical and other (e.g. psychological) forms of pressure. Broad standards such as these allow the courts to consider a range of matters relating to conduct, situation and terms which can help vulnerable consumers. The vulnerable consumer standard (examined above in the context of misleading actions) will be particularly relevant where traders are dealing face to face with consumers and are thereby in a position to assess the relevant matters, or where some characteristic of the consumer is known to the trader. Of course, the flexibility may concern traders who want a clearer picture of how far they can go to persuade consumers to act in the way(s) they want. Nevertheless, the provisions are to be welcomed as a welcome tool in protecting the interest of the vulnerable.

\section{Cooling Off Periods}

Cooling off periods have two main objectives. First, they protect individuals against high pressure sales, and are therefore of particular relevance to those sectors, or practices, where high pressure is likely to be found. Second, they allow consumers time to access more information about a transaction, and can therefore been seen to have a role in improving competition (Ramsay (date) $)^{18}$ They have been incorporated into legislation in a number of areas, including doorstep selling and distance selling.

\footnotetext{
${ }^{17}$ G. Howells, H-W. Micklitz and T. Wilhelmsson European Fair Trading Law (Ashgate, Aldershot 2006) 175.

${ }^{18}$ Ramsay (n 33) 330.
} 
Cooling off periods have several strengths as a form of regulation. First, they are relatively market-friendly, as they make it easier for consumers to impose market discipline by making better informed decisions and, if desired, switching from one product to another. ${ }^{19}$ However, in many cases, the period may be inadequate to allow the consumer to be fully informed. (Rekati and Van den Bergh (2000). ${ }^{20}$ Because they respect consumer choice, and place few burdens on traders, cooling off periods can be supported by those who favour market-based solutions to consumer detriment. They are, perhaps, examples of 'asymmetric paternalism' creating significant benefits for those who would otherwise make mistakes, but placing few burdens on other parties (Camerer (2003; Ramsay (date) $)^{21}$ Second, they provide an avenue of escape from a consumer who makes a decision under power asymmetry without the need for investigation into the circumstances.

Cooling off periods raise difficult distributional questions. In particular, they will most commonly be used by relatively well informed (rather than vulnerable) consumers. $^{22}$ Wilhelmsson suggests that measures which help consumers to protect themselves and discipline the market through the action they take may reproduce or even strengthen injustice as those most in need of protection are least able to take the required action (Wilhelmsson ()$) .{ }^{23}$ The impact on vulnerable consumers may be exacerbated by traders factoring the uncertainty created by cooling off periods into the price of contracts when, in practice, it will tend only to be less vulnerable consumers who take account on the protection. Cooling off periods play a role, but should not be heavily relied upon to protect the vulnerable.

\footnotetext{
${ }^{19}$ Howells sees cooling off periods as closely connected with information remedies. Howells (n 13) 79.

${ }^{20}$ P Rekaiti and R Van den Bergh 'Cooling Off Periods in the Consumer Laws of the EC Member States: a Comparative Law and Economics Approach’ (2000) 23 JCP 371-407.

${ }^{21} \mathrm{C}$ Camerer 'Regulation for Conservatives: Behavioural Economics and the Case for Asymmetric Paternalism' (2003) U Penn L Rev 1211-1254. Discussed in Ramsay (n 33) 346.

${ }^{22}$ See Citizen's Advice ‘Can you cancel it?'CAB Evidence Briefing (Citizen's Advice) 4.

${ }^{23}$ Wilhelmsson (n 14).
} 


\section{Responsibilising Firms}

A further way to address pressure vulnerability is to place obligations on firms to ensure that their products are appropriate.

\section{Pressure Vulnerability and the Consumer as Defendant}

Perhaps the starkest pressure vulnerability that consumers face is when they are confronted with legal action, for example for recovery of a debt. The regulation of how consumers who find themselves in default are treated is an area of great complexity and significance. It is particularly important that vulnerable consumers in default are protected from improper pressure from creditors. Some of these issues are examined below in the context of impact vulnerability.

\section{Identifying Supply Vulnerability}

In the perfect market, consumers have numerous buyers and sellers in each sector with whom they potentially can deal. In practice, such choice may be lacking. In an attempt to bettercapture the nature of consumer decision-making, Wilhelmsson offers several visions of the consumer. One of these is the 'consumer without choices' who has 'a need which must be satisfied...[but] little choice concerning the manner in which such satisfaction is obtained.' (Wilhelmsson (1996)) $)^{24}$ This lack of choice may lead to what is here called 'supply vulnerability', particularly where consumers lack products essential to health and well-being such as energy, food and healthcare. ${ }^{25}$ As has been stated 'to be excluded by poverty is to be denied the full freedom of choice which is supposed to be the pivot of a modern industrial

\footnotetext{
${ }^{24}$ T Wilhelmsson Twelve Essays on Consumer Law and Policy (University of Helsinki, Helsinki 1996) 110.

${ }^{25}$ National Consumer Council Paying More: Getting Less (NCC, London 2004)
} 
society.' (Golding (1996); Ramsay (date)) ${ }^{26}$ This demonstrates the close link between supply vulnerability and impact vulnerability. Even where products are not essential, consumers may sometimes feel pressurised through lack of choice to purchasing products they can ill-afford. In such cases, many consumers will become vulnerable to exploitation by unscrupulous suppliers and, in particular, loan sharks. The link to pressure vulnerability is apparent, particularly where there is a situational monopoly.

\section{Addressing Supply Vulnerability}

\section{Competition-Based Responses}

Supply vulnerability can sometimes be addressed by encouraging competition, for example through reducing barriers to entry or using competition law to increase the number of suppliers. However, there are concerns with such approaches. First, they may improve supply for some consumers without improving access for the more vulnerable. Second, some competition-enhancing initiatives, such as the removal of licensing requirements, may increase vulnerability by increasing the number of less reputable traders. ${ }^{27}$ Increasing competition should not be viewed as a panacea.

\section{Public Service Obligations}

Where products or services were traditionally provided by the public sector it is common to place public/universal service obligations on suppliers. This guarantees access to a service of a particular quality at an affordable price regardless of economic, social or geographical situation. ${ }^{28}$ The EC Treaty recognises the existence of 'services of general economic interest'

\footnotetext{
${ }^{26}$ P Golding (ed) Excluding the Poor (CPAG, London 1986) 76 (cited in Ramsay (n 34) at 96). See also D Caplowitz The Poor Pay More (Free Press, New York 1963).

${ }^{27}$ Note the effect of the introduction of prior approval for lenders. See Scott and Black (n 31) chap 12.

${ }^{28}$ P Rott 'Consumers and Services of General Interest: Is EC Consumer Law the Future?' (2007)(30)(1) JCP 4960.
} 
which are subjected to public service obligations through a criterion of general interest. ${ }^{29}$ Several Directives include public service obligations, including those on telecommunications, postal services, and energy markets. Public service obligations found in the Directives include the right of access, the right to affordable services, and the right to identical service under comparable conditions.

Public service obligations are an obvious response where consumers might otherwise lack some essential products, but how far should this go? Wilhelmsson argues for such obligations in areas such as in financial services on the bases of legitimate expectations and corporate responsibility (Wilhelmsson (2003)). ${ }^{30}$ On the first basis, while it is unlikely that consumers would believe they are entitled to expect access to all financial services, a case might be made for such access in relation to a basic bank account. Indeed, on $18^{\text {th }}$ July 2011 the European Commission published a recommendation urging member States to ensure all Europeans have access to basic banking services. ${ }^{31}$ In relation to corporate responsibility, Wilhelmsson suggests that consumers have a special trust in (some) corporations, which justifies imposing enhanced responsibility, that those corporations can easily redistribute any increased cost, and that should bear responsibility for problems they cause. ${ }^{32}$ The final point resonates particularly where banking is concerned. Of course, where other essential goods (such as food) are concerned, public service obligations are unlikely to be viable.

There is a danger that improving supply may sometimes be a cause of vulnerability, as consumers can become vulnerable as a result of being encouraged to access inappropriate

\footnotetext{
${ }^{29}$ See Commission Green Paper on Services of General Economic Interest COM (2003) 270 and Commission White Paper on services of General Economic Interest COM (2004) 374.

${ }^{30} \mathrm{~T}$ Wilhelmsson, 'Services of general interest and European private law' in C Rickett and T Telfer (eds), International Perspectives on Consumers' Access to Justice (CUP, Cambridge 2003) 149, 155. The concept of legitimate expectations was developed in particular by Hans Micklitz. See H-W Micklitz, 'Principles of Justice Within the European Union' in E Paasivirta and K Rissanen (eds), Principles of Justice and the Law of the European Union (Helsinki University, Helsinki 1995).

${ }^{31} \mathrm{http}$ ://eur lex.europa.eu/LexUriServ/LexUriServ.do?uri=OJ:L:2011:190:0087:0091:EN:PDF

${ }^{32}$ Wilhelmsson (n 75) 157.
} 
products. There is sometimes a case for tightening supply (for example through responsible lending provisions) as well as for expanding it. ${ }^{33}$

\section{Governmental Supply}

It is possible for the State to provide or subsidise essential goods and services. Simple examples of this include initiatives such as the social fund. The fund includes both a regulated scheme, which provides grants such as maternity, funeral and cold weather payments (which do not have to repaid) and a discretionary scheme, which provides budgeting and crisis loans (which are repayable but interest free). This raises important questions about boundaries: between consumer law and social policy; between public and private; between the market and the state. There is, of course, an extent to which the response to vulnerability is to reduce poverty, for example by trying to ensure distributive justice through the tax and benefits system. While such approaches are beyond the scope of this article, they should be remembered. Supply vulnerability has at its heart vulnerability through lack of choice, and, as Gabriel and Lang point out, 'the key barrier to consumer choice is money (Gabriel and Lang (2006)). ${ }^{, 34}$

\section{Identifying Redress Vulnerability}

In the perfect market, consumers exert market discipline, not only in choosing products, but also in holding suppliers to account and obtaining redress where those products are unsatisfactory. In practice, consumers may be vulnerable through the greater difficulties they face in securing redress (redress vulnerability). Again, there will be a connection here with other aspects of vulnerability. For example, consumers may find it difficult to secure redress

\footnotetext{
${ }^{33}$ See OFT Irresponsible lending: oft guidance for creditors (OFT 1107 March 2010, updated Feb 2011).

${ }^{34}$ Y Gabriel and T Lang The Unmanageable Consumer ( $2^{\text {nd }}$ ed, Sage London 2006) 32.
} 
because they are unaware of their legal rights, or of the mechanisms under which they can seek a resolution of their grievances. ${ }^{35}$ Alternatively, they may feel unable to take action because of pressure that has been applied to them. A lack of capacity and inclination to pursue redress are important factors in consumer vulnerability. ${ }^{36}$

In some cases, complaining will be sufficient to receive redress, but there is evidence that disadvantaged consumers are less inclined to complain than others. ${ }^{37}$ There are several explanations for this: vulnerable consumers may have lower expectations, less knowledge (of their rights, of how to complain) or less confidence (either in themselves or in the willingness of suppliers to respond to them). Consumers may also exert market discipline and obtain satisfaction by switching from one supplier to another, something that may be particularly difficult for some. Ultimately, redress may require litigation. Whether complaining, switching or suing, consumers face transaction costs, particularly in the form of enforcement costs. ${ }^{38}$ Obtaining redress may require knowledge, confidence and resources and the absence of these contributes to consumer vulnerability. In addition, consumers need effective and affordable mechanisms under which they can enforce rights against suppliers. The courts provide the paradigm for obtaining redress, but many consumers will find this prohibitive.

The barriers to obtaining redress constitute a significant and self-perpetuating source of vulnerability. Although reputable suppliers will be expected to make reparation on the basis of a justified complaint, it is less likely to be forthcoming from others. This is particularly problematic where 'fly by night' traders are concerned, and presents difficulties both for

\footnotetext{
${ }^{35}$ In the words of Barr, know how includes "knowing your entitlements...knowing your legal rights; and...your social and professional contacts". N Barr The Economics of the Welfare State (4 ${ }^{\text {th }}$ ed OUP, Oxford 2004).

${ }^{36} \mathrm{CAV}$ (n 5) para 4.2.

${ }^{37}$.Andreasen and Manning (n 8) 14

${ }^{38}$ Ramsay (n 33).
} 
individual consumers and for the operation of the market. ${ }^{39}$ Traders who know they are unlikely to be held to account may be under incentives to supply poor quality products and engage in improper conduct. Poorer consumers are particularly likely to deal with such traders.

Addressing Redress Vulnerability

Redress Through Voice

Some of the barriers faced by vulnerable consumers might be addressed by information/education-based responses, helping consumers to be more assertive. As will be seen below, others may only be addressed through greater intervention. Andreasen and Manning use the concept of 'amplified voicing' to describe where consumers enlist the help of third parties such as consumer groups and regulatory agencies to act on their behalf (Andreasen and Manning (1990)). ${ }^{40}$ It is a particular concern that any cuts to important sources of support (such as Citizens Advice) would impact disproportionately upon already vulnerable consumers. ${ }^{41}$

\section{Facilitating Litigation}

Where formal action is required, one response is to help consumers to obtain redress through the courts. An example is the introduction of the small claims procedures in the county court. ${ }^{42}$ Despite the user-friendly procedure envisaged by Justice out of Reach in $1970,{ }^{43}$ the

\footnotetext{
${ }^{39}$ See Anthony J Duggan 'Consumer access to justice in common law countries: a survey of issues from a law and economics perspective' in Rickett and Telfer (n 75) 46.

${ }^{40}$ Andreasen and Manning (n 8) 12.

${ }^{41}$ To a great extent these roles will in future be played by Citizens Advice.

${ }^{42}$ See for example I Ramsay 'Consumer Redress Mechanisms for Poor Quality and Defective Products' (1981)

31 University of Toronto Law Journal 117; W Whitford "Structuring Consumer Protection Legislation to

Maximise Effectiveness" (1981) Wisconsin Law Review 1018-1043; W van Boon and M Loos (eds) Collective Enforcement of Consumer Law (Europa Law Publishing, Groningen 2007)

${ }^{43}$ Consumer Council Justice out of Reach (HMSO, London 1971)
} 
reality has been a court which is used primarily by the 'well healed and articulate'. ${ }^{44}$ As Ramsay wryly observes: 'when [the poor] do appear, it is primarily as a defendant. (Ramsay (??)) ${ }^{45}$ This experience appears to be shared across the globe. ${ }^{46}$ It seems unlikely that the most vulnerable consumers will benefit where they are expected to take individual action before the courts, even where the process is simplified. Many users of the small claims process found it to be cumbersome, bureaucratic and intimidating. ${ }^{47}$ Furthermore, such figures ignore those 'lumpers' who are dissuaded from using the scheme in the first place (Genn (1999)). ${ }^{48}$ Alternatives are essential. They may come in the form of collective redress or, particularly importantly in the context of financial services, through alternative dispute resolution.

\section{Alternative Dispute Resolution}

Alternative dispute resolution (ADR) mechanisms allow consumers to by-pass the courts. They take a number of forms, and recognised by the Directive of May 2013 on Consumer ADR (Commission, 2013) ${ }^{49}$. Perhaps the most prominent example is the statutory Financial Ombudsman Scheme (FOS). Under the Scheme, the Ombudsman makes decisions 'by reference to what is, in his opinion, fair and reasonable in all the circumstances of the case' ${ }^{50}$ In making this judgement, the Ombudsman will take into account "the relevant law,

\footnotetext{
${ }^{44} \mathrm{~J}$ Baldwin Small Claims in County Courts in England and Wales: the Bargain Basement of Civil Justice? (OUP, Oxford 1997) 166. Cited in Ramsay (n 34) 233. This has been confirmed recently by a study for Consumer Focus. It found that the majority of small claims cases were issued through the County Court Bulk Centre which is only available to those claimants which issue large numbers of claims on a regular basis. See L Bello Small claims, big claims (Consumer Focus, London 2010) 4.

${ }^{45}$ Ramsay ibid.

${ }^{46}$ Duggan (n 85) 60.

${ }^{47}$ Bello (n 90) 4.

${ }^{48}$ See H Genn Paths to Justice: What People Do and Think About Going to Law (Hart, Oxford 1999). ${ }^{49}$ http://eur-ex.europa.eu/LexUriServ/LexUriServ.do?uri=OJ:L:2013:165:0063:0079:EN:PDF

${ }^{50}$ FSA DISP 3.8.1.R. Ombudsmen also exist in other sectors, including energy, communications, property and copyright.
} 
regulations, regulators' rules and guidance and standards, relevant codes of practice and, where appropriate, what he considers to have been good industry practice at the relevant time". ${ }^{51}$ This allows for considerable discretion to ensure justice in individual cases. It has been suggested that the test may be too wide. For example, commenting on a similar test found in private ombudsman schemes Lord Ackner suggested that they made the industry 'the hostage to fortune of uncertain and therefore unpredictable liability (Ackner (1993)). ${ }^{, 52}$ But there are also concerns that the needs of more vulnerable consumers may not be met. For example, Lord Hunt's Report concluded that 'the FOS still looks too much like a middle class service for middle class people' (Hunt, (2008)) ${ }^{53}$ However, it should be noted both that the FOS has made considerable efforts to broaden its appeal, and that any forms of redress scheme is likely to be used predominantly by those from higher income groups, particularly if the scheme is centred on financial services. ${ }^{54}$ The fact that the FOS is free at point of use, and that its staff are able to provide significant assistance to consumers make it particularly wellsuited to addressing the needs of vulnerable consumers.

Identifying Impact Vulnerability

The relationship between the perfect market and consumer vulnerability has been emphasised. The responses to vulnerability identified, such as tackling informational, pressure, supply and redress vulnerability, are all concerned to some extent with improving the working of the market for vulnerable consumers. They reduce the likelihood of consumers making adverse choices, and provide avenues of redress where breaches take place. While some of the solutions discussed above might also be classified as non-economic,

\footnotetext{
51 Ibid

${ }^{52}$ Lord Ackner, Report on a Unified Complaints Procedure (1993, London PIA) para 93.

${ }^{53}$ Lord Hunt Opening up, Reaching out and Aiming High (2008).

${ }^{54}$ See FOS Improving service to our users. Available at http://www.financialombudsman.org.uk/publications/policy-statements/accessibility.html (accessed 5-4-2012).
} 
or 'social' responses, in particular placing social obligations upon suppliers, they are nevertheless responses to market failure. ${ }^{55}$

It was noted above that Burden sees some consumers as vulnerable because they suffer greater loss through making inappropriate purchasing decisions (Burden (??)). ${ }^{56} \mathrm{CAV}$ also make reference to the difficulties some consumers may have in coping with the negative consequences of injury or loss when it occurs (CAV (??)). ${ }^{57}$ Where loss or harm impacts disproportionately upon certain consumers it may be described as impact vulnerability.

Where financial services are concerned, the principal contributor to impact vulnerability will be poverty. It may be that certain consumers are no more likely to make 'wrong' decisions than the majority: there has been no misleading information, no pressure applied, and there is ample choice. However, the consequences of that wrong choice impact particularly on certain consumers because they can ill-afford to make such mistakes. In 2000, research for the OFT concluded that a detriment of $£ 1$ suffered by a consumer with half the national average income was as significant as detriment of $£ 2.50$ suffered by a consumer with average income. ${ }^{58}$ Problems for low income consumers are compounded by the fact that they are likely to pay more than others for their goods and services (Andreasen (1975); Caplowitz $(? ?))^{59}$ Reasons for this include: the need to pay by cash; the inability to buy in bulk; the difficulty in accessing a variety of suppliers; and the tendency for suppliers to charge more, for example for credit. (National Consumer Council (2004)) ${ }^{60}$ Poverty is perhaps the most significant factor in vulnerability, as well as a constant justification for consumer law. As

\footnotetext{
${ }^{55}$ For the distinction between economic and non-economic rationales for regulation see A Ogus Regulation (OUP, Oxford 1994) chap 3.

${ }^{56}$ Burden (n 17).

${ }^{57} \mathrm{CAV}$ (n 5) para 3.1.

${ }^{58}$ OFT Welfare Weights (OFT 282, London 2000)

${ }^{59}$ See Caplowitz (n 71). See also A Andreasan The Disadvantaged Consumer (Free Press, New York, 1975); F Williams (ed) Why the Poor Pay More (NCC, London 1977) and, most recently, National Consumer Council Paying More: Getting Less (NCC London 2004).

${ }^{60}$ NCC Ibid.
} 
Ramsay has observed: '[the alleviation of problems of poverty and the disadvantaged...has been a continuing undercurrent in consumer protection.' (Ramsay (??)) ${ }^{61}$ Indeed, the previous Government recognised that 'the poorest in society are least able to afford the consequences of bad decisions. ${ }^{62}$ Impact vulnerability exists regardless of whether the supplier is in breach of the law; indeed, it is particularly apparent where a consumer is in debt and faces action from creditors. Consumer law has traditionally focused primarily on the consumer as claimant or complainant, seeking redress for the wrongs of a supplier. But it is vital also to recognise the needs of consumers when they face action, particularly that from creditors. ${ }^{63}$

Addressing Impact Vulnerability

\section{Market-Based Solutions}

One way of addressing impact vulnerability is to reduce the chance of the consumer making a decision that will have such an impact. It can, therefore, be tackled by addressing the other forms of vulnerability identified and discussed above. However, it is clear that some consumers will, even in a well-functioning market, make decisions which are particularly detrimental. To some extent this is inevitable; the freedom to make decisions means the freedom to make (some) mistakes. ${ }^{64}$ But an environment which provides no form of relief for the consumer facing a significant burden is unlikely widely to be regarded as acceptable.

\section{Product Regulation}

Product regulation is most commonly considered where consumers are at risk from products that pose an unacceptable danger to physical well-being. But it might also be considered as a way of protecting consumers from financial products. This has recently received attention in

\footnotetext{
${ }^{61}$ I Ramsay (n 33) 88.

${ }^{62}$ HM Government Modern Markets: Confident Consumers (HMSO London 1999).

${ }^{63}$ Below.

${ }^{64}$ T Schelling Choice and Consequence (Harvard University Press, Cambridge 1984) 144.
} 
the financial services field as a result of the FSA's suggestion that it might play a greater role in intervening in financial product design. ${ }^{65}$ Indeed, the FSA recognised the argument that financial products could be so liable to cause detriment that they should ultimately be banned. ${ }^{66}$ COMMENT, FCA ETC

One way in which products might be regulated is through controls on price. The UK has tended to treat such controls with great scepticism, and many commentators suggest that controlling prices is typically an inefficient method of achieving distributive justice. ${ }^{67}$ Credit ceilings, common in much of Europe, are perhaps the most obvious example of price controls aimed at reducing impact vulnerability but have been opposed on a range of grounds. ${ }^{68}$ There is little doubt that short-term loans to borrowers with poor credit histories involve very high annual percentage rates (APRs), commonly over $4000 \%$ APR. The UK Government announced in 2012 that it would give the Financial Conduct Authority the power to set interest rate ceilings. ${ }^{69}$ There is concern from some quarters that this could leave many poorer consumers without access to lawful credit. ${ }^{70}$ This is a difficult subject and one that divides observers starkly. It is submitted that the exclusionary effect of credit ceilings can be alleviated by the provision of appropriate alternatives, for example through governmental supply of low-cost credit for essentials. ${ }^{71}$

Compensation Schemes and Safety Nets

\footnotetext{
${ }_{65}^{65}$ FSA Product Intervention (DP 11/1 January 2011).

${ }^{66}$ Ibid para 2.27.

67.

${ }_{69}^{68}$ OFT Review of High Cost Credit (OFT 1232 London 2010).

${ }^{70}$ Ibid.

${ }^{71}$ See above.
} 
Like information regulation, product regulation reduces ex ante the likelihood of impact vulnerability materialising. Other tools may be used to reduce the impact ex post. Public policy provides a range of responses to impact vulnerability in the form of safety nets. Unemployment and sickness benefits are obvious examples. ${ }^{72}$ But there may also be a role for consumer protection law. One example is the Financial Services Compensation Scheme (FSCS) which provides compensation if a financial services firm is unable, or likely to be unable, to pay claims against it (for example because it has been declared to be in default). The FSCS now protects a range of products, namely: deposits, insurance policies, and insurance broking; investment business, and home finance. Although the deposit insurance element of the Scheme in particular has an important role in maintaining confidence in the sector, the principal rationale for compensation schemes is consumer protection. It is possible to see the basis of compensation schemes as information asymmetry, with consumers unable to make informed choices about the soundness of an institution with which they deal. But such schemes might also be justified on the basis of the significant loss that would be suffered by consumers when a firm fails. Less affluent consumers in particular frequently have a large proportion of their assets in the form of deposits. Furthermore, as well as standing to lose the highest proportion of their assets, vulnerable consumers are likely to be the least able to judge the soundness of an institution, making it particularly important to provide a safety net. In the past, the deposit insurance scheme was weighted towards protecting a higher proportion of the deposits of the least affluent. Now that $100 \%$ protection up to the total of $£ 85,000$ is protected, the overwhelming majority of depositors have full cover.

\footnotetext{
${ }^{72}$ Barr draws a distinction between the 'Piggy Bank' and the 'Robin Hood' functions of the welfare state. It is the latter which seeks to relieve poverty and reduce social exclusion by redistributing income and wealth. See N Barr The Welfare State as Piggy Bank (2001, Oxford, OUP).
} 
Safety nets may benefit vulnerable consumers in other ways. For example, courts could examine whether bargains become unacceptably onerous because of changes in circumstances. Wilhelmsson identifies four characteristics of 'social force majeure' schemes found in Nordic law to illustrate how this might operate (Wilhelmsson, 1990). ${ }^{73}$ First, the consumer is affected by some special occurrence, such as an unfavourable change to health, work, housing or family. Typical examples might be physical illness, unemployment, termination of a lease or divorce. Secondly, there has to be a causal link between that occurrence and the consumer's ability to meet particular obligations. Thirdly, the consumer must not have foreseen the special occurrence at the time that the contract was concluded. Finally, the occurrence must not be the consumer's fault. The effects would depend on the particular case in point. For example, suppliers might have their remedies restricted or be prevented from avoiding the contract, and consumers might be able to withdraw from, or terminate the contract.

Like compensation schemes, social force majeure schemes operate as a form of flexible compulsory insurance policy. They apply where the consumer becomes (more) vulnerable after having entered the contract and so operate as a kind of safety net in the event of unanticipated events which affect the ability of consumers to meet their obligations. From the perspective of reducing impact vulnerability, such schemes appear attractive, but they raise concerns (Collins, 1999) ${ }^{74}$ First, there is an argument that they generate moral hazard. Knowing that they will be protected in the event of adverse circumstances, consumers may be more willing to take unjustified risks. However, as the circumstances must have been both unforeseen and have occurred without fault on the part of the consumer, this is mitigated. Secondly, social force majeure may make it more difficult to construct markets. There are a number of ways in which the courts can challenge a contract on the basis of its being unfair,

\footnotetext{
73 See T Wilhelmsson "'Social Force Majeure” - A New Concept in Nordic Consumer Law” (1990) 13 JCP 1.

${ }^{74}$ H Collins Regulating Contracts (OUP, Oxford 1999) chap 11.
} 
most obviously under the Unfair Terms in Consumer Contracts Regulations. Although the courts are likely to be influenced by the fairness of the outcome, their task is to consider whether the term is unfair of itself, the focus being on the position of the parties at the time that they entered the contract. With social force majeure, the question is whether the provision is now unfair, bearing in mind what has happened. Traders will not be in a position to identify, when the contract is formed, the result should the consumer default. While this is a potential concern, the cost can be managed, for example through insurance. Thirdly, there is a danger that social force majeure might be exclusionary, either by raising the cost of a transaction (to incorporate the prices of default and uncertainty) or by reducing supply by disincentivising traders from entering (or continuing in) the market. These concerns should be taken seriously, but it is submitted that they do not present an insurmountable hurdle. As discussed above, many of the objections apply similarly to tools such as cooling off periods and they do not appear to have been unduly problematic.

In the UK, these issues are well known in the area of consumer credit and debt with debtors frequently unable, rather than unwilling, to meet their obligations. The relationship between controlling creditors' remedies and other aspects of consumer protection of the vulnerable has been noted; Ramsay, for example, suggests that 'an enforcement system that does not protect debtors' rights may result in an over-extension of credit or create incentives for irresponsible or fraudulent marketing. (Ramsay ??) ${ }^{, 75}$ Regulation may operate in a variety of ways, including improving information, requiring court orders before action is taken, and restructuring or writing down debt. ${ }^{76}$ It is beyond the scope of this article to examine this in depth, but it remains one piece in the jigsaw.

\section{Conclusions}

\footnotetext{
${ }^{75}$ Ramsay (n 33) 580.

${ }^{76}$ Ibid chap 10; P Cartwright The Vulnerable Consumer of Financial Services: Law Policy and Regulation (Financial Services Research Forum, Feb 2011).
} 
This article has proposed a taxonomy of vulnerability which helps to identify (a) what makes consumers particularly vulnerable, and (b) how consumer protection law and policy can respond to these and so ensure that such consumers are appropriately protected. The article recognises the value of competitive markets, and suggests how consumer law and policy may provide appropriate protection to vulnerable consumers without placing unwieldy or counterproductive obligations upon traders.

Deciding how the interests of vulnerable consumers should be protected requires careful consideration and judgement. The proposed taxonomy aims to provide a useful tool through which some of the key issues can be addressed. While the issues might be viewed as matters primarily for legislators, regulators and courts, they have implications for others too. For example, traders concerned about whether their sales and marketing methods are fair to vulnerable consumers may decide to use the taxonomy to help answer this. While it will not always provide a definitive answer, it should help both to clarify the questions to be asked, and to illuminate the responses. Of course, an optimum system which encourages and respects consumer choice, but which also ensures that the most vulnerable are protected appropriately is difficult to design. This article considers the factors such a system might have to take into account. Despite the steps that can be taken, some problems will remain intractable, especially those related to poverty. As Caplowitz concluded: 'until poverty is eradicated, only limited solutions to ...[the poor's] problems as consumers can be found. ${ }^{, 77}$

\section{Bibliography}

Lord Ackner, Report on a Unified Complaints Procedure (1993, London PIA) para 93. G Akerlof 'The Market for Lemons: quality uncertainty and the market mechanism' (1970) 84 Quarterly Journal of Economics 488-500

A Andreasan The Disadvantaged Consumer (Free Press, New York,1975);

A Andreasen and J Manning 'The Dissatisfaction and Complaining Behavior of Vulnerable Consumers' CD/D\&CB (vol 3, 1990) 12-20,

\footnotetext{
${ }^{77}$ Caplowitz (n 126) 191-2.
} 
J Baldwin Small Claims in County Courts in England and Wales: the Bargain Basement of Civil Justice? (OUP, Oxford 1997) 166.

N Barr The Economics of the Welfare State ( $4^{\text {th }}$ ed OUP, Oxford 2004).

N Barr The Welfare State as Piggy Bank (2001, Oxford, OUP)

$\mathrm{H}$ Beales, R Craswell and S Salop 'The efficient regulation of consumer information' (1981) 24 Journal of Law and Economics 491;

L Bello Small claims, big claims (Consumer Focus, London 2010) 4

A Best When Consumers Complain (Columbia University Press, New York 1981) 28

S Beyer, Regulation and its Reform (Harvard University Press, Cambridge 1982) 151.

BIS The Role and Powers of the Consumer Advocate (BIS December 2009) para 27

BRE/BERR/NCC Warning! Regulated Information: a Guide for Policy Makers (undated ) 14.

BRE/BERR/NCC Warning: Too Much information can harm (Final Report, undated) 13

R Burden Vulnerable Consumer Groups: Quantification and Analysis (OFT Research Paper 15, April 1998)

C Camerer 'Regulation for Conservatives: Behavioural Economics and the Case for Asymmetric Paternalism' (2003) U Penn L Rev 1211-1254. Discussed in Ramsay (n 33) 346.

D Caplowitz The Poor Pay More (Free Press, New York 1963).

P Cartwright The Vulnerable Consumer of Financial Services: Law Policy and Regulation (Financial Services Research Forum, Feb 2011)

P Cartwright 'Under Pressure: Regulating Aggressive Commercial Practices in the UK'

[2011] Feb LMCLQ 123-141.

D Cayne and MJ Trebilcock 'Market Considerations in the Formulation of Consumer

Protection Policy' (1973) 23 University of Toronto Law Journal 396-430, 406

Citizen's Advice 'Can you cancel it?'CAB Evidence Briefing (Citizen's Advice) 4.

H Collins Regulating Contracts (OUP, Oxford 1999)

$\mathrm{H}$ Collins 'Harmonisation by Example: European Laws against Unfair Commercial

Practices' (2010) 73(1) MLR 89-118, 104-105

Consumer Affairs Victoria What do we mean by vulnerable and disadvantaged

consumers? (Consumer Affairs Victoria, Melbourne 2004)

Consumer Affairs Victoria What do we mean by vulnerable and disadvantaged consumers? (Consumer Affairs Victoria, Melbourne 2004)

Consumer Council Justice out of Reach (HMSO, London 1971)

M Doyle, K Ritters and S Brooker Seeking Resolution: the availability and usage of

consumer to business alternative dispute resolution in the United Kingdom (DTI/NCC) urn 03/1616 Jan 2004.

DTI Comparative Report on Consumer Policy Regimes (DTI, London Oct 2003) 9

Anthony J Duggan 'Consumer access to justice in common law countries: a survey of issues from a law and economics perspective' in Rickett and Telfer (n 75) 46

FSA Product Intervention (DP 11/1 January 2011)

Y Gabriel and T Lang The Unmanageable Consumer ( ${ }^{\text {nd }}$ ed, Sage London 2006) 32

H Genn Paths to Justice: What People Do and Think About Going to Law (Hart, Oxford 1999).

M George and L Lennard 'At a disadvantage' (2007) 17(2) Consum PR 56-61, 56

P Golding (ed) Excluding the Poor (CPAG, London 1986) 76 (cited in Ramsay (n 34) at 96).

HM Government Modern Markets: Confident Consumers (HMSO London 1999).

G Hadfield, R Howse and M Trebilcock 'Information-Based Principles for Rethinking

Consumer Protection Policy' (1998) 21 Journal of Consumer Policy 131-169.

J Hansen and D Kysar 'Taking Behaviouralism Seriously: The Problem of Market

Manipulation' (1999) 74 New York University Law Review 630.

G Howells 'The Potential and Limits of Consumer Empowerment by Information' (2005)

32(3) Journal of Law and Society 349.

G. Howells, H-W. Micklitz and T. Wilhelmsson European Fair Trading Law (Ashgate, Aldershot 2006) 175. 
London Economics Consumer Detriment Under Conditions of Imperfect Information (OFT

Research Paper 11 - August 1997);

Lord Hunt Opening up, Reaching out and Aiming High (2008).

C Jolls, CR Sunstein and R Thaler 'Behavioural Approach to Law and Economics' (1998)

Stanford Law Review 1470;

E Kempson and C Whyley Kept Out or Opted Out? Understanding and Combating

Financial Exclusion (Policy Press, London 1999).

A Kronman 'Contract Law and Distributive Justice' (1980) Yale LJ 472-511, 480

A Leff 'Injury, Ignorance and Spite - the Dynamics of Coercive Collection' (1970) 80 Yale LJ 1-46).

S Menzel Baker, JW Gentry and TL Rittenberg 'Building Understanding of the Domain of Consumer Vulnerability' (2005) 25(2) Journal of Macromarketing 1-12;

$\mathrm{H}-\mathrm{W}$ Micklitz, 'Principles of Justice Within the European Union' in E Paasivirta and $\mathrm{K}$ Rissanen (eds), Principles of Justice and the Law of the European Union (Helsinki University, Helsinki 1995).

FW Morgan DK Schuler and JL Stoltman 'A Framework for Examining the Legal Status of Vulnerable Consumers' (1995) 14(2) Journal of Public Policy and Marketing 267-277

R Mulheron The Class Action in Common Law Legal Systems (Hart, Oxford 2004).

R Mulheron "Some Difficulties with Group Litigation Orders - And Why a Class Action is Superior" (2005) 24 CJQ 40-68

National Consumer Council Paying More: Getting Less (NCC London 2004).

OFT Review of High Cost Credit (OFT 1232 London 2010)

OFT Welfare Weights (OFT 282, London 2000)

OFT Irresponsible lending: oft guidance for creditors (OFT 1107 March 2010, updated Feb 2011)

A Ogus Regulation (OUP, Oxford 1994)

J Peysner and A Nurse Representative Actions and Restorative Justice: A Report for the Department for Business Enterprise and Regulatory Reform (Lincoln Law School, December 2008)

I Ramsay Consumer Law and Policy ( $2^{\text {nd }}$ ed) (Hart, Oxford 2007) 71-84.

Ramsay ??(1981) 31 University of Toronto Law Journal 117;

I Ramsay Advertising Culture and the Law (Sweet and Maxwell London 1996) 85

$P$ Rekaiti and R Van den Bergh 'Cooling Off Periods in the Consumer Laws of the EC

Member States: a Comparative Law and Economics Approach' (2000) 23 JCP 371-407.

DJ Ringold 'Social Criticisms of Target Marketing: Process or Product' (1995) 38

American Behavioural Scientist 578-592, 584

L Robinson "A 7 step social marketing approach" paper at the Waster Educate 98

Conference cited in Consumer Affairs Victoria Social Marketing and Consumer Policy

(Research paper no.4 March 2006).

P Rott 'Consumers and Services of General Interest: Is EC Consumer Law the Future?' (2007)(30)(1) JCP 49-60.

H Sants 'Delivering Intensive Supervision and Credible Deterrence' (Speech, 12 March 2009). Available at

http://www.fsa.gov.uk/library/communication/speeches/2009/0312 hs.shtml. (accessed 9-4-12).

T Schelling Choice and Consequence (Harvard University Press, Cambridge 1984) 144

C Scott and J Black Cranston's Consumers and the Law ( $3^{\text {rd }}$ ed, Butterworths, London 2000) 372

H Simon Models of Bounded Rationality (MIT Press, Cambridge, 1982).

NC Smith and E Cooper-Martin 'Ethics and Target Marketing: The Role of Product Harm and Consumer Vulnerability' (1997) 61 Ethics and Target Marketing 1-20, 4

C Sunstein, Free Markets and Social Justice (OUP, New York, 1997) 284

C Twigg Flesner, D Parry, G Howells and A Nordhausen An Analysis of the Application and Scope of the Unfair Commercial Practices Directive (DTI, London 2005).

W van Boon and M Loos (eds) Collective Enforcement of Consumer Law (Europa Law Publishing, Groningen 2007) 
W Whitford "Structuring Consumer Protection Legislation to Maximise Effectiveness" (1981) Wisconsin Law Review 1018-1043;

WC Whitford 'The Functions of Disclosure Regulation in Consumer Transactions' (1973) Wisconsin Law Review 400-70;

T Wilhelmsson "'Social Force Majeure" - A New Concept in Nordic Consumer Law' (1990) 13 JCP 1

T Wilhelmsson Twelve Essays on Consumer Law and Policy (University of Helsinki, Helsinki 1996) 110.

T Wilhelmsson, 'Consumer Law and Social Justice' in I Ramsay (ed), Consumer Law in Global Economy (Ashgate, Aldershot 1997) 217.

$\mathrm{T}$ Wilhelmsson, 'Services of general interest and European private law' in C Rickett and T Telfer (eds), International Perspectives on Consumers' Access to Justice (CUP, Cambridge 2003) 149, 155.

$T$ Wilhelmsson 'The Informed Consumer $v$ the Vulnerable Consumer in European Unfair Commercial Practices Law - A Comment' in G Howells, a Nordhausen, D Parry and C Twigg-Flesner (eds) Yearbook of Consumer Law 2007 (Ashgate, Aldershot 2007) 211, 213

F Williams (ed) Why the Poor Pay More (NCC, London 1977)

J Ziegel 'The Future of Canadian Consumerism' (1973) Canadian Bar Review 190. Cited in I Ramsay (n 33) 53 